\section{AIDS mortality, "race or color", and social inequality in a context of universal access to highly active antiretroviral therapy (HAART) in Brazil, 1999-2004}

\author{
Mortalidade por AIDS, "raça/cor" e desigualdade \\ social, em um contexto de acesso universal à \\ terapia anti-retroviral de alta potência \\ (HAART) no Brasil, 1999-2004
}

\author{
Maria Goretti P. Fonseca 1,2 \\ Francisca de Fátima A. Lucena ${ }^{3}$ \\ Artur de Sousa ${ }^{3}$ \\ Francisco I. Bastos 4
}

\footnotetext{
${ }^{1}$ Instituto de Pesquisa Evandro Chagas, Fundação Oswaldo Cruz, Rio de Janeiro, Brasil. 2 Diretoria Regional de Brasília, Fundação Oswaldo Cruz, Brasília, Brasil. 3 Secretaria de Vigilância em Saúde, Ministério da Saúde, Brasília, Brasil.

4 Instituto de Comunicação

e Informação Científica e Tecnológica em Saúde, Fundação Oswaldo Cruz, Rio de Janeiro, Brasil.

Correspondence M. G. P. Fonseca Diretoria Regional de Brasília, Fundação Oswaldo Cruz. SEPN 510 - Ministério da Saúde, Unidade II, 4o andar sala 407, Brasília, DF 70750-520, Brasil. gorettifonseca@fiocruz.br
}

\begin{abstract}
Highly active antiretroviral therapy (HAART) has led to a substantial increase in the survival of people living with AIDS, despite heterogeneities among individuals from different socioeconomic strata. The present paper analyzes AIDS deaths in Brazil during a period in which HAART became a key treatment regimen, exploring the hypothesis that "race or color" defines one dimension of socioeconomic inequality in Brazil. AIDS mortality, stratified by gender and "race or color", was calculated using data from the National Mortality System. The rates were highest among individuals classified as "black" and lower among those classified as "mixed-race", with a continuous increase among the later from 1999 to 2004 for men and women. Among individuals classified as "white", mortality rates remained stable among men, but not women. Median age at death among "mixedrace" individuals was lower for both men and women. Differential trends according to gender and "race or color" were highlighted by the present study, indicating the pressing need to further explore the underlying factors that might explain different mortality rates in a context of universal access.
\end{abstract}

Acquired Immunodeficiency Syndrome; Highly Active Antiretroviral Therapy; Race or Ethnic Group Distribution; Mortality; Social Inequality

\section{Introduction}

Since theidentification of the first case of acquired immunodeficiency syndrome (AIDS) in the United States and the realization that there was a vigorous ongoing epidemic in sub-Saharan Africa in the early 1980s, AIDS has been defined as a pandemic of enormous magnitude and scope. AIDS became a leading cause of death among young adults, with pronounced impacts on society, the economy, and family structure and dynamics in the most affected areas. According to the Joint United Nations Programme on HIV/AIDS (UNAIDS), in 2005 approximately 40 million people were living with HIV/AIDS, with 4 million new infections and 2.8 million deaths secondary to AIDS worldwide 1 .

Highly active antiretroviral therapy (HAART) has led to a substantial increase in the survival of persons living with AIDS (PLWAs) 2, but with clear differences according to socioeconomic and demographic characteristics ${ }^{3}$. Of special concern, however, is the fact that a huge number of PLWAs in developing countries, especially in sub-Saharan Africa, lack access to antiretroviral therapy (ART) ${ }^{4}$.

Early diagnosis, speedy referral to treatment, and effective engagement in treatment are key elements for improved prognosis and longer survival 5 .

The AIDS epidemic has been especially dynamic in Brazil, with various changes such as the 
decrease in the number of AIDS cases among injection drug users (except for southern Brazil, where the decline has been slight or there has even been an increase in recent years in some municipalities ${ }^{6}$ ) and the proportional increase of AIDS cases secondary to heterosexual transmission 6 and among disadvantaged population strata 7,8 .

AIDS deaths have been decreasing since the mid-1990s, roughly following the trends in AIDS incidence 9 , with a marked additional effect secondary to the substantial increase in survival after the introduction of HAART 10, despite clear heterogeneities between men and women and across different geographic regions 11 .

With the ongoing change in the epidemic's socioeconomic profile, it is essential to verify whether the universal ART access policy adopted by the Brazilian Ministry of Health since 199612 has led to a real reduction in AIDS mortality inequalities in Brazil.

The present study aims to assess AIDS mortality during two decades of the epidemic in Brazil, with special emphasis on the period since the introduction of HAART. The variable "race or skin color" was used as one dimension of social inequality in a country plagued by deep contrasts, generally combining social, economic, and geographic inequalities. For the sake of the present analyses, we assume that the "race or skin color" variable (hereinafter "race/color") has been associated with other social and economic inequalities, as shown by data documenting labor market and income differentials between "whites" and "blacks" 13.

\section{Methodology}

AIDS deaths reported to the Brazilian Mortality Information System (SIM; http://www.datasus. gov.br/catalogo/sim.htm) were analyzed. For the time period 1980-1995, the code 279.1 (Deficiency of cell-mediated immunity) of the International Classification of Diseases, Injuries, and Causes of Death - $9^{\text {th }}$ Revision (ICD-9) ${ }^{14}$ was used as the code for AIDS. Code 279.1 is considered an excellent proxy for AIDS, since other forms of cellular immunodeficiency are extremely rare. For the time period 1996-2004, the specific codes for AIDS of the 10th revision of the ICD (ICD-10) 15, B20-B24 (Human immunodeficiency virus [HIV]) were used instead.

Aiming to assess the impact of socioeconomic inequality on AIDS differential mortality, the race/color variable was used as an indicator of the socioeconomic status of individuals who died as a consequence of AIDS from 1999 to 2004, when that variable was included in the SIM data- base, with good reliability for the purposes of the present analysis.

Mortality rates were calculated using Brazil's population estimates disaggregated by race/color as provided by the Instituto Brasileiro de Geografia e Estatística [Brazilian National Institute of Geography and Statistics] (IBGE; http://www.ibge.gov.br). Distribution of the race/color variable as self-reported by interviewees in the National Household Sample Survey (PNAD) for the years 1999, 2001, and 2003, by gender, was applied to the population estimates, and interpolated for the years 2000, 2002, and 2004.

Secular AIDS mortality trends by race/color were evaluated through the annual percentage variation of rates for each race/color category, by sex, and adjusted by an exponential regression model fitted against time (1999-2004). Nonpaired t tests were applied to the angular coefficients to verify the statistical significance of the secular trends.

AIDS deaths were compared to deaths from other causes and ranked among the main causes of death in Brazil, by sex, in the 15-54-year age group. A coding system and spreadsheet especially designed for the purpose, the ICD-BR-10, created by experts from the Brazilian Ministry of Health, was used, comparing mortality data from 1996 (the first year of ICD-10 implementation and the beginning of HAART in Brazil) to 2004 (http://tabnet.datasus.gov.br/cgi/sim/obtcid10br.htm). For sake of comparison, the first subcategory related to the abovementioned list was used, after excluding deaths due to external causes (ICD-BR-10 codes 103-112) and those that occurred in the absence of medical assistance or resulted from ill-defined causes (ICD-BR-10 codes 100-102). Deaths with AIDS as the underlying cause were included in the subcategory "viral infections".

The proportion of AIDS deaths according to the disaggregated fourth-character subcategories of Human immunodeficiency virus [HIV] cause of death (ICD-10 codes B20.0-B23.8) was analyzed by gender for the 15-54-year age group, comparing 1996 and 2004. For the years 1999 to 2004, additional analyses assessed differential mortality by race/color.

\section{Results}

From 1980 to 2004, 172,000 AIDS deaths were reported to SIM. The median number of monthly reported AIDS deaths increased 22.6\% per year from 1990 to 1996 , reaching $1,269.5$ deaths by the end of the period, despite relative stabilization of monthly death reports since 1995 . 
Beginning in mid-1996 the number of deaths declined substantially, leveling off thereafter under a threshold of 1,000 AIDS deaths per month, until 2004 (Figure 1). Mortality rates were invariably higher among men than women (Table 1) over the years under analysis, reaching 15.1 per 100,000 in 1995 , with a subsequent decrease to $8.5 / 100,000$ in 2004, corresponding to a decrease of $44 \%$ compared to 1995 . Among women, a less pronounced reduction was observed after 1996. AIDS mortality rates in women leveled off in 2001 , with 4 deaths per 100,000 , after a peak of $4.8 / 100,000$ in 1996. This differential decrease in AIDS deaths by gender, over time, may partially explain the pronounced decrease in the male-tofemale ratio over time, varying from 23:1 in 1985 to $2.2: 1$ in 2004 (Table 1).

Median age at death among individuals over 12 years of age varied from 33 to 34 among males from 1987 to 1997. Thereafter, it followed a continuous upward trend, reaching 39 years in 2004. Among females, the corresponding median remained relatively stable, around 32-33 years, from 1991 to 1997, but increasing in the subsequent period, reaching a median of 37 in 2004 (Table 1).

Among all deaths due to "viral infections" from 1996 to 2004, according to ICD-BR-10 at least $90 \%$ were AIDS deaths for both men and women. Thus, for comparison purposes in this article, the relative position of deaths due to "viral infections" will be taken as a proxy for the relative position of AIDS deaths in ranking major causes of death in Brazil.

In 1996, among deaths with a known cause, after excluding those secondary to external causes, AIDS (i.e., "viral infections") ranked as the first cause of death among males aged 15-54 years ( $12 \%$ of the total), and fourth among causes of death in females in the same age group $(6.4 \%$ of the total) (Figure 2).

In 2004, AIDS was the fourth cause of death in males $(7.8 \%$ of the total) and fifth in females (5.5\%).

Table 2 provides data on AIDS mortality rates, annual variation (\%), and respective $p$-values, according to race/color, by gender, from 1999 to 2004. The race/color categories "Asian" and "Indigenous" were excluded from the analysis since they represented only $1.2 \%$ of all deaths in the period (for both genders).

AIDS mortality rates in white males remained stable throughout the target period. AIDS deaths among black males increased by $4.9 \%$ per year $(p=0.072)$, with a steeper annual increase of $7.4 \%$ ( $\mathrm{p}=0.048$ ) up to 2003 , and a subsequent decline in 2004, when the rates returned to the 2002 levels.
AIDS mortality rates in mixed-race males remained the lowest of the three race/color groups under analysis, despite an upward trend of 3.8\% per year $(\mathrm{p}=0.019)$.

The figures were somewhat different in women. For white women there was a $3.8 \%$ mean yearly increase $(p=0.075)$, contrasting with the trends for men. For black women, AIDS mortality increased at a fast pace until 2001, from 7.0 to 9.8 deaths / 100,000 women, stabilizing thereafter, with a mean annual increase of $6.4 \%$ for the entire target period.

Overall mortality among black women was 2.3-2.7 times that of whites. Such differential mortality decreased in 2004, but remaining as a greater disparity than that observed among men. The latter differentials are again unfavorable for black men, with rates 1.8 those of whites. Mixedrace individuals showed the lowest rates, despite a constant and steep yearly increase of $7 \%$ ( $p=$ 0.004) in females.

Median age at death from AIDS for males over 12 years of age varied from 36 to 39 years for both whites and blacks, but the variation was less pronounced among the latter, reaching a median of 39 years in 2004. Meanwhile, median age at death for mixed-race individuals was consistently lower, although increasing from 34 to 38 during the same period.

Median age at death for women was consistently lower among those classified as mixedrace (35-37 years) as compared to whites and blacks (34-38 and 35-38, respectively).

The proportional distribution of AIDS deaths by underlying cause and respective subcategories (using a four-digit coding system) was then tabulated by gender and race/color, among individuals 15-54 years of age.

The years 1999 to 2004 were used as the standard years for comparison, due to the high proportion of deaths classified as "unspecified human immunodeficiency virus [HIV] disease" (B24) in the preceding years (i.e., the B24 category corresponded to less than $20 \%$ of AIDS deaths only after 1998).

Over the years, AIDS deaths classified as "resulting in infectious and parasitic diseases" (B20) prevailed, with nearly $80 \%$ of the total for both men and women. Among the deaths in the B20 category, $30 \%$ were classified as "resulting in other infectious and parasitic diseases" (B20.8). This subcategory decreased slightly over the years, in parallel with an increase in deaths "resulting in multiple infections" (B20.7), which increased from $28 \%$ of the total in 1999 to $35 \%$ in 2004.

AIDS deaths classified as "resulting in mycobacterial infection" (B20.0 - "resulting in tubercu- 
Number of AIDS deaths * according to month of occurrence, by gender. Brazil, July 1985-July 2004.

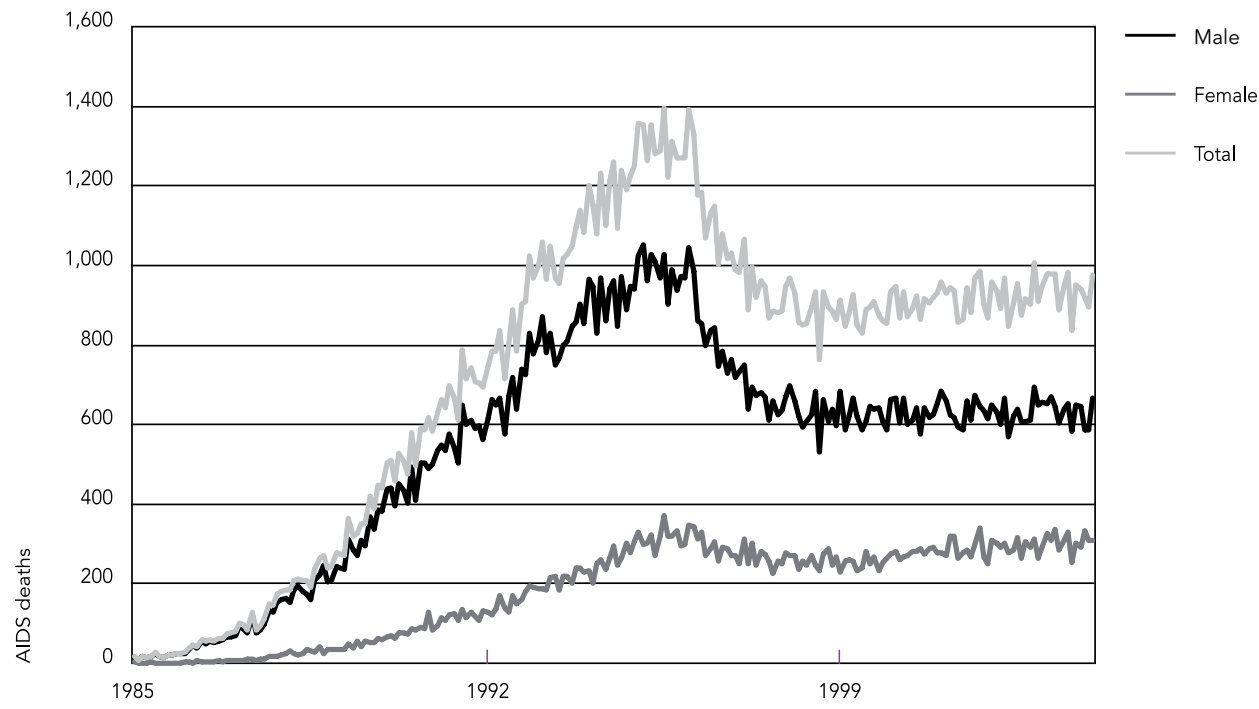

Source: Brazilian Mortality Information System (SIM; http://www.datasus.gov.br/catalogo/sim.htm).

* Up to 1995 the ICD-9 14 code 279.1 was used. From 1996 on, ICD-10 15 codes B20-B24 were used.

losis") were slightly more common among males, with a decrease from $14 \%$ to $10 \%$ from 1999 to 2004, a trend similar to that observed in females (from $11.5 \%$ to $9.5 \%$ in the same period).

Deaths "resulting in other specified diseases" (B22) corresponded to roughly $15 \%$ of the total, with no discernible trend over the years. Among these deaths, those "resulting in multiple diseases classified elsewhere" (B22.7) varied from $67.5 \%$ in 1999 to $74.4 \%$ in 2004 , with roughly similar trends for women, although with lower proportions.

No significant differences were found when AIDS deaths from 1999 to 2004 were analyzed by race/color for both men and women. Deaths "resulting in infectious and parasitic diseases" (B20) were slightly more frequent among blacks and "mixed-race individuals as compared to whites. Meanwhile, deaths "resulting in malignant neoplasms" (B21), although quite rare, corresponding to only $3 \%$ of the underlying causes, were slightly more prevalent among whites as compared to blacks and mixed-race.

Figure 3 shows the proportional distribution of the five main fourth-character subcategories of Human immunodeficiency virus [HIV] (codes B20.0-B23.8) cause of death in males ages 15 to 54 . The subcategories "resulting in other infec- tious and parasitic diseases" (B20.8) and "resulting in multiple infections" (B20.7) were the first and second most frequent causes of death, respectively, for individuals belonging to any of the three race/color categories for both men and women in 1999.

A reversal of the previous trends was observed in 2004, with a proportional reduction of $15 \%$ in deaths classified as B20.8 and a 35\% increase of those classified as B20.7 among both whites and blacks. However, there were relevant differences in deaths "resulting in mycobacterial infection" (B20.0 - "resulting in tuberculosis"). These represent the third cause among black and mixedrace males, but the fourth among whites, with a sharp reduction among the latter from 1999 to 2004. The patterns in women were quite similar to those observed in men.

\section{Discussion}

The present paper documents changes in Brazilian AIDS mortality trends over time, especially relevant since the latter half of 1996, with the introduction of HAART. Due to the complexity of the new treatment regimens, in December 1996 the Brazilian Ministry of Health issued the first 
Mortality rate (per 100,000 inhabitants), sex ratio, and median age at death *, according to sex, by year. Brazil, 1985 to 2004.

\begin{tabular}{|c|c|c|c|c|c|}
\hline \multirow[t]{2}{*}{ Year of death } & \multicolumn{2}{|c|}{ Rate } & \multirow{2}{*}{$\begin{array}{c}\text { Sex ratio } \\
\text { Male/Female }\end{array}$} & \multicolumn{2}{|c|}{ Median age at death } \\
\hline & Male & Female & & Male & Female \\
\hline 1985 & 0.23 & 0.01 & 23.0 & 34 & - \\
\hline 1986 & 0.55 & 0.03 & 18.3 & 35 & - \\
\hline 1987 & 1.30 & 0.12 & 10.8 & 34 & - \\
\hline 1988 & 2.61 & 0.36 & 7.3 & 34 & 31 \\
\hline 1989 & 4.06 & 0.61 & 6.7 & 34 & 32 \\
\hline 1990 & 6.51 & 1.03 & 6.3 & 33 & 31 \\
\hline 1991 & 8.46 & 1.65 & 5.1 & 33 & 32 \\
\hline 1992 & 10.15 & 2.08 & 4.9 & 33 & 32 \\
\hline 1993 & 12.35 & 2.89 & 4.3 & 33 & 32 \\
\hline 1994 & 13.94 & 3.58 & 3.9 & 34 & 33 \\
\hline 1995 & 15.08 & 4.48 & 3.4 & 34 & 33 \\
\hline 1996 & 14.43 & 4.81 & 3.0 & 34 & 33 \\
\hline 1997 & 11.12 & 4.10 & 2.7 & 34 & 33 \\
\hline 1998 & 9.61 & 3.77 & 2.5 & 35 & 34 \\
\hline 1999 & 9.26 & 3.64 & 2.5 & 35 & 34 \\
\hline 2000 & 9.02 & 3.70 & 2.4 & 37 & 35 \\
\hline 2001 & 8.80 & 3.89 & 2.3 & 37 & 36 \\
\hline 2002 & 8.80 & 3.90 & 2.3 & 37 & 36 \\
\hline 2003 & 8.80 & 4.00 & 2.2 & 38 & 37 \\
\hline 2004 & 8.50 & 3.90 & 2.2 & 39 & 37 \\
\hline
\end{tabular}

Source: Brazilian Mortality Information System (SIM; http://www.datasus.gov.br/catalogo/sim.htm).

* Age at death for individuals over 12 years of age. Figures for females refer only to 1988 and later, due to the small number

of deaths in the previous years.

version of its HIVIAIDS Treatment Guidelines 16, aiming to inform and guide health professionals on the proper use of antiretroviral treatment (ART) and drugs for prophylaxis of opportunistic diseases.

Since the early 1990s Brazil had already been distributing ARVs 17, although erratically, and such policy became better organized, with the distribution of guidelines 16 and reorganization and accreditation of services for optimal management and care for PLWAs. Such concerted efforts contributed to country's dramatic decline in AIDS mortality, followed by its relative stabilization at a much lower threshold.

The Federal government launched its comprehensive ARV distribution effort in December 1996 18, but the medicines had been supplied previously by some State and Municipal Health Authorities. For instance, São Paulo, Brazil's most industrialized State and that most heavily affected by the AIDS epidemic, provided combination ART since August 199619.

As of late 1996 a steep decline in AIDS mortality was observed, along with a progressive in- crease in median age at death and a decrease in the proportion of AIDS death in Brazil's all-cause mortality ranking.

Universal free access to ARVs has since remained a key dimension of Brazilian health policy, guaranteeing to PLWAs who are eligible for ART (as defined by the abovementioned guidelines) the provision of full medication as needed. This policy has been considered highly successful, especially in the context of a developing country like Brazil, plagued by deep socioeconomic and regional inequalities 20,21 .

Women appear not to have benefited from HAART as much as men. Although women showed lower mortality rates than men, increases in AIDS deaths among women in recent years are a major concern. Such increases may reflect specific difficulties faced by women living with AIDS. Meanwhile, the mobilization of gay men since the very beginning of the epidemic in Brazil may partially explain the observed gender differences, since a relevant proportion of men have been actively engaged in the struggle against HIV/AIDS for many years. 
Figure 2

Distribution (\%) of the main cause of death * among individuals aged 15 to 54 years, by gender. Brazil, 1996 and 2004 .

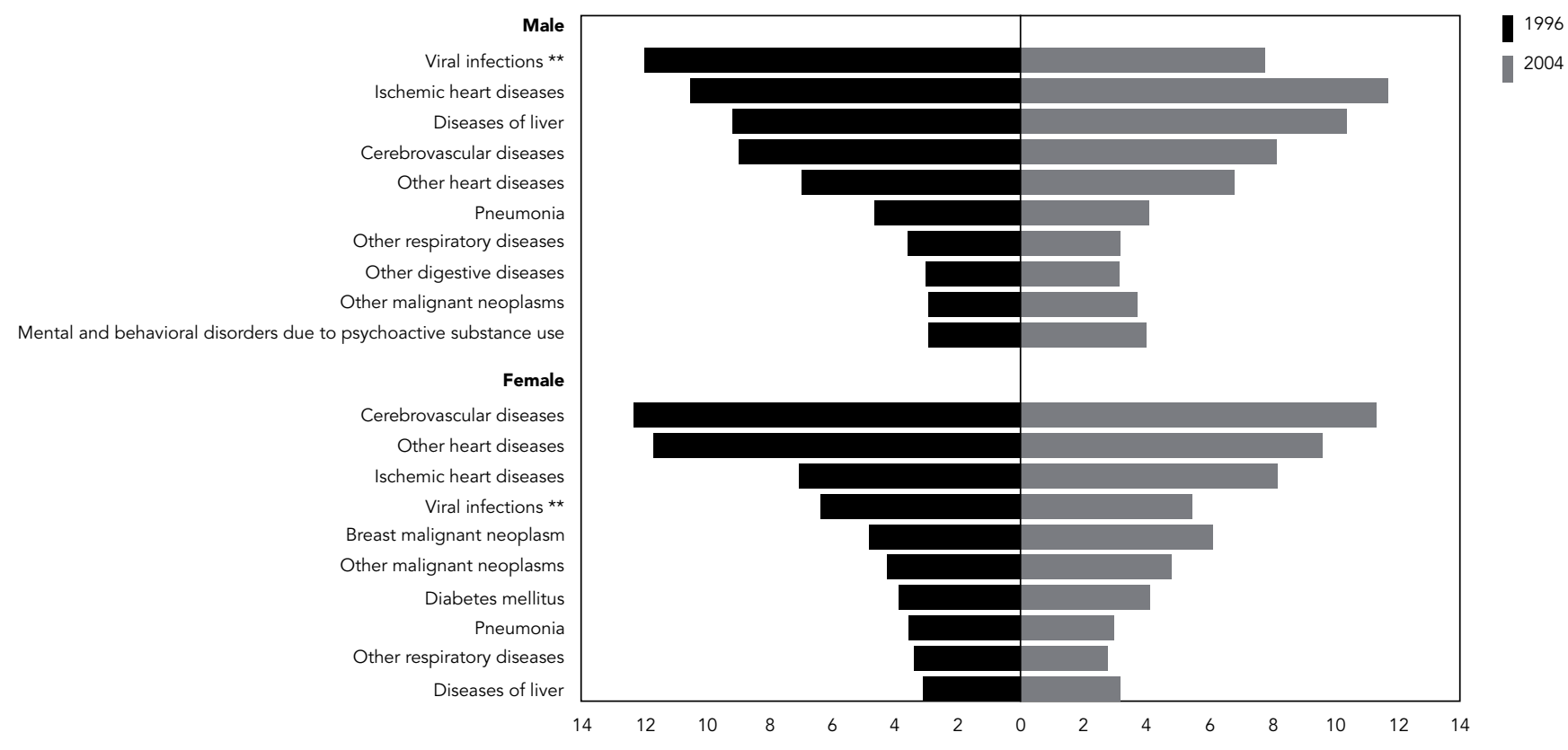

Source: Brazilian Mortality Information System (SIM; http://www.datasus.gov.br/catalogo/sim.htm).

* Subcategories of the Brazilian ICD-BR-10 list (http://tabnet.datasus.gov.br/cgi/sim/obtcid10br.htm);

** Deaths due to human immunodeficiency virus (HIV) disease were included in the subcategory "Viral infections".

A paper published in 1998 on an AIDS reference hospital in Rio de Janeiro showed worse prognosis for women living with AIDS on ART as compared men 22 , but such findings were not corroborated by subsequent studies 9 . Government initiatives at different levels to improve and expand HIV testing for pregnant women and prevent motherto-child HIV transmission of HIV 23 contributed to timely diagnosis and counseling of women, but the pressing need to provide their speedy referral to quality care remains a key concern 24 .

The study of social inequalities in health has used different indicators to compare populations with different socioeconomic conditions and address the associations between demographic, social, and economic variables and different health outcomes. Variables such as race/color have been targeted in studies assessing health inequality in heterogeneous countries like the United States 25 and Brazil 26.

A consistent association between higher socioeconomic status and longer survival in AIDS patients has been documented in the United States, both in the pre-HAART 27 and postHAART eras 28. In Brazil, less than optimal access to health services among impoverished populations 29,30 and higher morbidity and mortality in blacks and/or mixed-race (compared to whites) have been documented by various studies $31,32,33,34$.

Although AIDS mortality rates have remained stable among men in the last decade, the increasing rates in blacks and the still low but increasing rates among mixed-race individuals are a major concern. Such differences may translate into worse prognosis for those populations, probably reflecting a combination of delayed entry into treatment, higher losses to follow-up, and/ or low adherence, compared to other population groups 35 . However, the absence of a linear gradient between whites, mixed-race, and blacks speaks in favor of subtle and complex interrelationships between color/race and health conditions in Brazil. 
AIDS mortlity rate (per 1000,000 inhabitants) and annual variation (\% and p value), according to race/color, by sex and year of death. Brazil, 1999 to 2004.

\begin{tabular}{lcccccccc}
\hline $\begin{array}{l}\text { Mortality } \\
\text { rate per 100,000 }\end{array}$ & $\mathbf{1 9 9 9}$ & $\mathbf{2 0 0 0}$ & $\mathbf{2 0 0 1}$ & $\mathbf{2 0 0 2}$ & $\mathbf{2 0 0 3}$ & $\mathbf{2 0 0 4}$ & \multicolumn{2}{c}{$\begin{array}{c}\text { Ynnual variation } \\
\text { \% value }\end{array}$} \\
\hline Male & & & & & & & & \\
$\quad$ White & 9.0 & 9.3 & 9.3 & 9.2 & 9.5 & 9.0 & 0.2 & 0.799 \\
$\quad$ Black & 12.3 & 15.5 & 15.8 & 16.2 & 17.2 & 16.1 & 4.9 & 0.072 \\
$\quad$ Mixed-race & 4.4 & 4.9 & 5.0 & 5.4 & 5.2 & 5.4 & 3.8 & 0.019 \\
$\quad \begin{array}{l}\text { Female } \\
\quad \text { White }\end{array}$ & 3.0 & 3.4 & 3.7 & 3.6 & 3.9 & 3.6 & 3.8 & 0.075 \\
$\quad$ Black & 7.0 & 7.9 & 9.8 & 9.6 & 9.5 & 9.7 & 6.4 & 0.043 \\
$\quad$ Mixed-race & 2.0 & 2.2 & 2.5 & 2.7 & 2.7 & 2.8 & 7.0 & 0.004 \\
\hline
\end{tabular}

Source: Brazilian Mortality Information System (SIM; http://www.datasus.gov.br/catalogo/sim.htm).

Figure 3

Distribution (\%) of the main fourth-character subcategories of cause of death due to HIV disease (ICD-10 15, codes 20.0 to B23.8), among male individuals aged 15 to 54, according to race/color, by year of death. Brazil, 1996 and 2004.

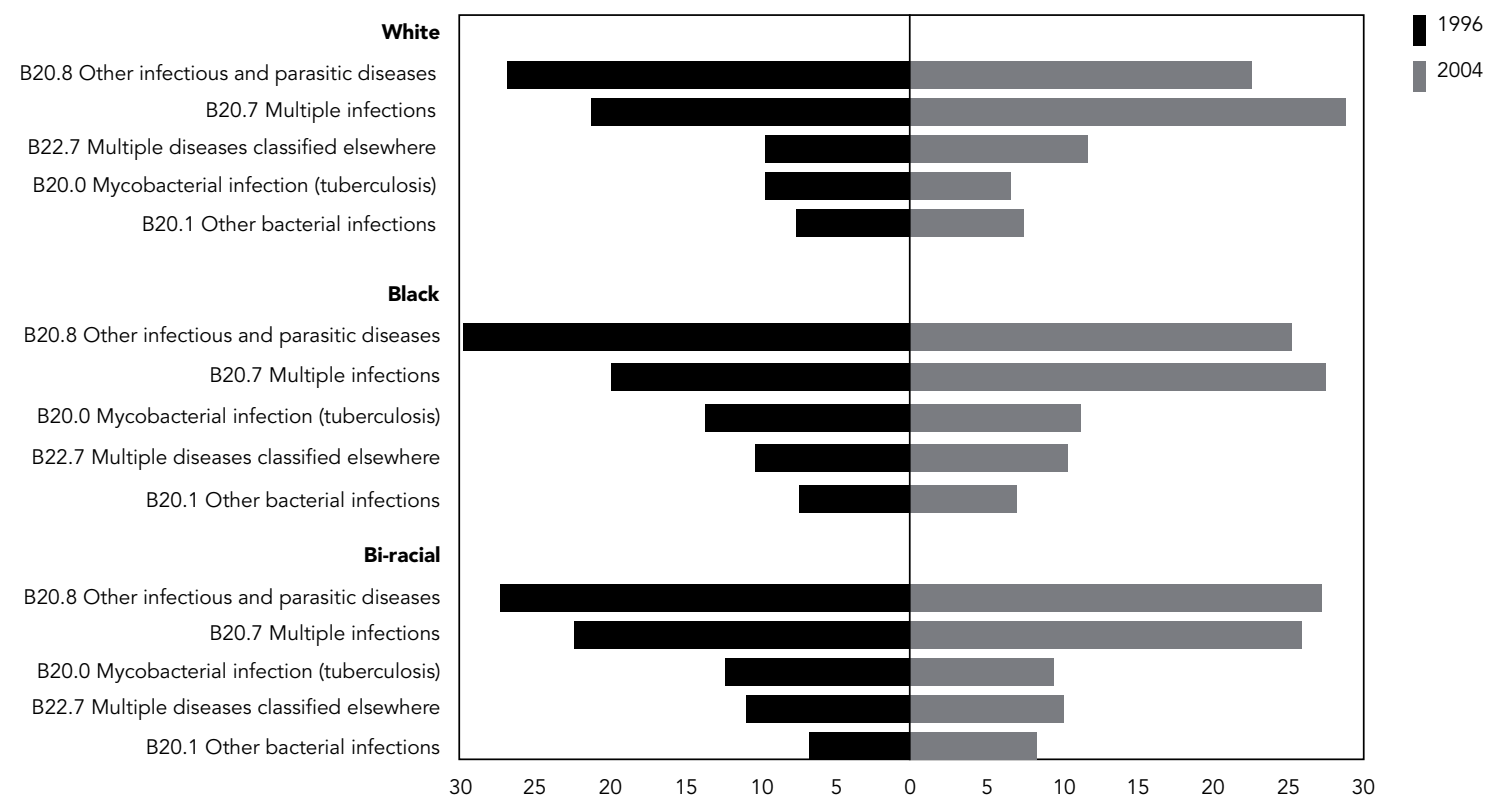

Source: Brazilian Mortality Information System (SIM; http://www.datasus.gov.br/catalogo/sim.htm)

Studies using a more sophisticated classification of race/color, such as that by Caetano 36 , are still lacking in the field of HIV/AIDS in Brazil. The author employed a combination of self-reported and interviewer-classified race/color (using both crude and adjusted data) to assess sterilization among Brazilian women, and unlike previous reports, did not find a linear gradient between women classified as white, mixed-race, or black in detriment to the latter (i.e. in terms of abusively high sterilization rates among mixed-race and black women). 
In the present study, we used race/color as defined by the corresponding variable in the SIM, with the well-known limitations in terms of inaccuracy and misclassification. One must also observe that in a country like Brazil with such extensive miscegenation, one must be cautious when using concepts and classifications employed by North American epidemiologists, as discussed by Travassos \& Williams 37 .

Former studies document the progressive change in the socioeconomic profile of AIDS cases in Brazil, with the proportional increase in new cases among disenfranchised social strata 7,8 . Late diagnosis of HIV infection has been associated with higher morbidity and mortality $17,38,39,40,41$ and should be further explored according to different covariates, such as gender, race/color, and social class.

Brazilian Unified National Health System (SUS) is based on a permanent quest for equal and fair access to quality treatment. Public policies fostering universal access to any modality of care may help reduce mortality between different social segments 42 . In this sense, the inequalities evidenced by the current study, regardless of their association with gender, race/color, or social class or a combination of these variables merits further study. Public policies aiming to remedy prevailing inequalities should improve access to treatment and standard-of-care for all clients of the SUS, reinforcing the basic principle of equal treatment for any all, regardless of individual characteristics or social status 34

The exclusive utilization of secondary data, not validated by original empirical data, poses limitations to the current study. However, Brazil's SIM has improved its data in terms of completeness and accuracy 26,43. A previous study validated information from the system using quantitative and qualitative data from 15 Brazilian municipalities. The study showed that for deaths presumed to be associated with AIDS but which did not originally include AIDS as the underlying cause, only $10.7 \%$ were defined, after careful review, as additional deaths associated with AIDS 43 .

The present study did not identify major differences in specific causes of death after the introduction of HAART, as demonstrated by the recent international literature 38 , although the analysis of cohort studies rather than secondary data from national databases, as in the present study, may explain the contrasting findings. Nevertheless, further studies are still needed to verify whether AIDS patients that die in health facilities are unaware of their HIV status, thus leading to incorrect recording of cause of death.

The current gap in studies on the differential survival of people living with AIDS by gender, socioeconomic status, and race/color reinforces the need for further exploratory analyses 26 .

Race/color as an indicator of the socioeconomic status of deceased individuals is based on previous studies documenting the concentration of individuals classified as black and mixed-race in the most dispossessed strata in Brazil 13,44,45. Due to a protracted and unjust development process, Brazil historically became one of the most unequal societies in the world 46 . Such inequalities have been associated with different socioeconomic and demographic variables, such as those related to social class, race/color, occupation, schooling, and gender.

The ongoing debate interprets Brazil's social and racial inequality according to two different hypotheses: one group views the social heterogeneities in terms of race/color as a consequence of underlying social and economic heterogeneities 47 , while the other sees the inequalities as directly related to race/color, as contended by some North American studies that explore the hypothesis that a racist society has unequal health standards, invariably unfavorable to racial/ethnic minorities 48 . In Brazil, the latter hypothesis has been explored by studies showing differential access to services and provision of care under different standards of quality in detriment to black and mixed-race individuals 49 . However, such studies are restricted to specific contexts and should be viewed with caution. Last but not least, recent Brazilian studies have found that race/color is an independent predictor of health status, after adjusting for other social and demographic variables 50 .

Despite the abovementioned limitations, this is the first paper to explore inequalities in AIDS mortality in a context of universal access. Further studies should address the most different dimensions of management and care for people living with AIDS in Brazil, since regardless of gender, race/color, sexual orientation, and social class they are entitled to receive optimal care and overcome difficulties in access to treatment, adherence, or psychosocial support. 


\section{Resumo}

A terapia anti-retroviral de alta potência (HAART) tem determinando substancial aumento da sobrevida de pessoas vivendo com AIDS, ainda que de forma heterogênea entre populações de diferentes condições sociais e econômicas. Este estudo analisa a mortalidade por AIDS no Brasil, num período em que a HAART se consolida como estratégia terapêutica, explorando a hipótese da variável "raça/cor" constituir uma das vertentes das desigualdades sociais e econômicas no Brasil. Foram calculadas taxas de mortalidade por AIDS, por sexo e "raça/cor", utilizando-se dados do Sistema de Informações sobre Mortalidade. As maiores taxas de mortalidade foram observadas nos indivíduos de "raça/cor" preta e as menores naqueles de "raça/cor" parda, ainda que com crescimento persistente no período observado (1999-2004), em ambos os sexos. Entre os indivíduos de "raça/cor" branca, observou-se estabilidade na taxa de mortalidade apenas entre os homens. A idade mediana dos óbitos na "raça/cor" parda foi invariavelmente mais baixa, para ambos os sexos. Tendências diferenciadas por sexo e "raça/cor" foram observadas, exigindo estudos adicionais que explorem os fatores que determinam diferenciais nas taxas de mortalidade num contexto de acesso universal.

Síndrome de Imunodeficiência Adquirida; Terapia Anti-Retroviral de Alta Atividade; Distribuição por Raça ou Etnia; Mortalidade; Desigualdade Social

\section{References}

1. The Joint United Nations Programme on HIV/ AIDS. 2006 Report on the global AIDS epidemic. A UNAIDS 10th anniversary special edition: executive summary. Geneva: World Health Organization; 2006.

2. Palella Jr. FL, Delaney KM, Moorman AC, Loveless MO, Fuhrer J, Satten GA, et al. Declining morbidity and mortality among patients with advanced human immunodeficiency virus infection. HIV Outpatient Study Investigations. N Engl J Med 1998; 338:853-60.

3. Fordyce EJ, Singh TP, Nash D, Gallagher B, Forlenza S. Survival rates in NYC in the era of combination ART. J Acquir Immune Defic Syndr 2002; 30:111-8.

4. Montaner JS, Hogg R, Wood E, Kerr T, Tyndall M, Levy AR, et al. The case for expanding access to highly active antiretroviral therapy to curb the growth of the HIV epidemic. Lancet 2006; 368:531-6.

5. Sighem AI, Wiel MA, Ghani AC, Jambroes M, Reiss P, Gyssens IC, et al. Mortality and progression to AIDS after starting highly active antiretroviral therapy. AIDS 2003; 17:2227-36.

6. Hacker MA, Leite IC, Renton A, Torres TG, Grace R, Bastos FI. Reconstructing the AIDS epidemic among injection drug users in Brazil. Cad Saúde Pública 2006; 22:751-60.

\section{Contributors}

M. G. P. Fonseca participated in the conception, data analysis, writing, and final editing of the manuscript. F. F. A. Lucena contributed to the data analysis and writing the manuscript. A. Sousa collaborated in the data analysis. F. I. Bastos collaborated in the conception, writing, and final editing of the manuscript.

\section{Acknowledgments}

The authors wish to acknowledge the invaluable contributions by Valdiléa Gonçalves Veloso of the Instituto de Pesquisa Clínica Evandro Chagas, Fundação Oswaldo Cruz [Evandro Chagas Clinical Research Institute, Oswaldo Cruz Foundation], and Gerson Fernando Mendes Pereira and Orival Silveria of the Brazilian National STD/AIDS Program.
7. Fonseca MGP, Bastos FI, Derrico M, Andrade CLT, Travassos C, Szwarcwald CL. AIDS e grau de escolaridade no Brasil: evolução temporal de 1986 a 1996. Cad Saúde Pública 2000; 16 Suppl 1:S77-87.

8. Fonseca MGP, Travassos C, Bastos FI, Silva NV, Szwarcwald CL. Distribuição social da AIDS no Brasil, segundo participação no mercado de trabalho, ocupação e status sócio-econômico dos casos de 1987 a 1998. Cad Saúde Pública 2003; 19:135163.

9. Hacker MA, Petersen ML, Enriquez M, Bastos FI. Highly active antiretroviral therapy in Brazil: the challenge of universal access in a context of social inequality. Rev Panam Salud Pública 2004; 16:7883.

10. Marins JR, Jamal LF, Chen SY, Barros MB, Hudes ES, Barbosa AA, et al. Dramatic improvement in survival among adult Brazilian AIDS patients. AIDS 2003;17:1675-82.

11. Fonseca MG, Barreira D. A evolução da mortalidade por AIDS no país, segundo sua distribuição geográfica. Boletim Epidemiológico AIDS; Ano XIII, no. 3.

12. Chequer P, Cuchí P, Mazin R, Calleja JMG. Access to antiretroviral treatment in Latin American countries and the Caribbean. AIDS 2002;16:550-7. 
13. Heringer R. Desigualdades raciais no Brasil: síntese de indicadores e desafios no campo das políticas públicas. Cad Saúde Pública 2002; 18 Suppl: S57-65.

14. Organização Mundial da Saúde. Manual da classificação estatística internacional de doenças, lesões e causas de óbitos - 9a conferência de revisão. São Paulo: Centro Brasileiro de Classificação de Doenças em Português; 1985.

15. Organização Mundial da Saúde. Classificação estatística internacional de doenças e problemas relacionados à saúde - 10a revisão. São Paulo: Centro Colaborador da OMS para a Classificação de Doenças em Português; 1995.

16. Ministério da Saúde. Guia de condutas terapêuticas em HIV/AIDS - 1996. Brasília: Programa Nacional de DST e AIDS, Ministério da Saúde; 1996.

17. Ministério da Saúde. Terapia anti-retroviral e saúde pública: um balanço da experiência brasileira. Brasília: Programa Nacional de DST e AIDS, Ministério da Saúde; 1999.

18. Ministério da Saúde. National AIDS drug policy. Brasília: Programa Nacional de DST e AIDS, Ministério da Saúde; 2001.

19. Gianna MC, Kalichman AO, Bueno SM, Basso CR, Ruiz EA, Tayra A, et al. Survival among AIDS patients by situations before and after HAART availability at STD/AIDS training and referral center, São Paulo, Brazil. In: XIV International Conference on AIDS. v.1. São Paulo: Centro de Referência e Treinamento DST/AIDS, Secretaria de Estado de Saúde de São Paulo; 2004. p. 157.

20. Galvão J. Access to antiretroviral drugs in Brazil. Lancet 2002; 360:1862-5.

21. Galvão J. Brazil and access to HIV/AIDS drugs: a question of human rights and public health. Am J Public Health 2005; 95:1110-6.

22. Santoro-Lopes G, Harrison LH, Moulton LH, Lima LA, Pinho AM, Hofer C, et al. Gender and survival after AIDS in Rio de Janeiro, Brazil. J Acquir Immune Defic Syndr Hum Retrovirol 1998; 19:403-7.

23. Ministério da Saúde. Portaria no. 569. Programa de humanização no pré-natal e nascimento no SUS. Diário Oficial da União 2000; 8 jun.

24. Fehringer J, Bastos FI, Massard E, Maia L, Pilotto JH, Kerrigan D. Supporting adherence to highly active antiretroviral therapy and protected sex among people living with HIV/AIDS: the role of patient-provider communication in Rio de Janeiro, Brazil. AIDS Patient Care STDS 2006; 20:637-48.

25. Williams D. The monitoring of racial/ethnic status in the USA: data quality issues. Ethn Health 1999; 4:121-37.

26. Chor D, Lima CRA. Aspectos epidemiológicos das desigualdades raciais em saúde no Brasil. Cad Saúde Pública 2005; 21:1586-94.

27. Easterbrook PJ, Keruly JC, Creagh-Kirk T, Richman DD, Chaisson RE, Moore RD. Racial and ethnic differences in outcome in zidovudine-treated patients with advanced HIV disease. Zidovudine Epidemiology Study Group. JAMA 1991; 266:2713-8.

28. Jain S, Schwarcz S, Katz M, Gulati R, McFarland W. Elevated risk of death for African-Americans with AIDS, San Francisco, 1996-2002. J Health Care Poor Underserved 2006; 17:493-503.
29. Rocha JS, Simões BJ, Guedes GL. Assistência hospitalar como indicador da desigualdade social. Rev Saúde Pública 1997; 31:479-87.

30. Almeida C, Travassos C, Porto S, Labra ME. Health sector reform in Brazil: a case study of inequity. Int J Health Serv 2000; 30:129-62.

31. Olinto MTA. Raça e desigualdade entre as mulheres: um exemplo no sul do Brasil. Cad Saúde Pública 2000; 16:1137-42.

32. Martins AL, Tanaka ACD. Mulheres negras e mortalidade materna no estado do Paraná, Brasil, de 1993 a 1998. Rev Bras Crescimento Desenvolv Hum 2000; 10:27-38.

33. Barros FC, Victora CG, Horta BL. Ethnicity and infant health in southern Brazil: a birth cohort study. Int J Epidemiol 2001; 30:1001-8.

34. Batista LE. Masculinidade, raça/cor e saúde. Ciênc Saúde Coletiva 2005; 10:71-80.

35. Lopes F. Mulheres negras e não negras vivendo com HIV/AIDS no Estado de São Paulo: um estudo sobre suas vulnerabilidades [Doctoral Dissertation]. São Paulo: Faculdade de Saúde Pública, Universidade de São Paulo; 2003.

36. Caetano AJ. A relação entre cor da pele/raça e esterilização no Brasil: análise dos dados da Pesquisa Nacional sobre Demografia e Saúde - 1996. In: Monteiro S, Sansone L, organizadores. Etnicidade na América Latina: um debate sobre raça, saúde e direitos reprodutivos. Rio de Janeiro: Editora Fiocruz; 2004. p. 229-48.

37. Travassos C, Williams DR. The concept and measurement of race and their relationship to public health: a review focused on Brazil and the United States. Cad Saúde Pública 2004; 20:660-78.

38. Palella Jr. FJ, Baker RK, Moorman AC, Chmiel JS, Wood KC, Brooks JT, et al. Mortality in the highly active antiretroviral therapy era: changing causes of death and disease in the HIV outpatient study. J Acquir Immune Defic Syndr 2006; 43:27-34.

39. Castilla J, Sobrino P, De La Fuente L, Noguer I, Guerra L, Parras F. Late diagnosis of HIV infection in the era of highly active antiretroviral therapy: consequences for AIDS incidence. AIDS 2002; 16:1945-51.

40. Hogg RS, Yip B, Chan KJ, Wood E, Craib KJ, O'Shaughnessy MV, et al. Rates of disease progression by baseline CD4 cell count and viral load after initiating triple-drug therapy. JAMA 2001; 286:2568-77.

41. Anastos K, Barron Y, Miotti P, Weiser B, Young M, Hessol N, et al. Risk of progression to AIDS and death in women infected with HIV-1 initiating highly active antiretroviral treatment at different stages of disease. Arch Intern Med 2002; 162:1973-80.

42. Antunes JL, Waldman EA, Borrell C. Is it possible to reduce AIDS deaths without reinforcing socioeconomic inequalities in health? Int J Epidemiol 2005; 34:586-92.

43. Jorge MHPM, Gotlieb SLD, Laurenti R. O sistema de informações sobre mortalidade: problemas e propostas para seu enfrentamento. I - mortes por causas naturais. Rev Bras Epidemiol 2002; 5:197211. 
44. Hasenbalg C, Silva NV. Raça e oportunidades educacionais no Brasil. In: Hasenbalg C, Silva NV, organizadores. Relações raciais no Brasil contemporâneo. Rio de Janeiro: Rio Fundo Editora; 1992. p. 79-100.

45. Henriques R. Desigualdade racial no Brasil: evolução das condições de vida na década de 90 . Rio de Janeiro: Instituto de Pesquisa Econômica Aplicada; 2001. (Texto para Discussão, 807).

46. Cardoso-de-Mello JM. O capitalismo tardio. São Paulo: Editora Brasiliense; 1982.

47. Kamel A. Não somos racistas. Rio de Janeiro: Editora Nova Fronteira; 2006.
48. Krieger N, Sidney S. Racial discrimination and blood pressure: the CARDIA Study of young black and white adults. Am J Public Health 1996; 86:1370-8.

49. Leal MC, Gama SG, Cunha CB. Racial, sociodemographic, and prenatal and childbirth care inequalities in Brazil, 1999-2001. Rev Saúde Pública 2005; 39:100-7.

50. Chor D, Faerstein E, Kaplan GA, Lynch JW, Lopes CS. Association of weight change with ethnicity and life course socioeconomic position among Brazilian civil servants. Int J Epidemiol 2004; 33:100-6.

Submitted on 13/Nov/2006

Final version resubmitted on 20/Sep/2007

Approved on 21/Sep/2007 